\title{
Analysis of United States Quantitative Easing Policy on Real Output in Indonesia
}

\author{
${ }^{*}$ Viphindrartin, Sebastiana, ${ }^{2}$ Yunitasari, Dwi \& ${ }^{3}$ Wilantari, Regina Niken \\ ${ }^{*}$ Economics and Business Faculty, Universitas Jember, Indonesia \\ ${ }^{2}$ Economics and Business Faculty, Universitas Jember, Indonesia \\ ${ }^{3}$ Economics and Business Faculty, Universitas Jember, Indonesia \\ Note: * Indicates corresponding author
}

\begin{tabular}{|c|c|}
\hline ARTICLE DETAILS & ABSTRACT \\
\hline $\begin{array}{l}\text { Article History } \\
\text { Published Online: publisher use } \\
\text { only }\end{array}$ & \multirow{4}{*}{$\begin{array}{l}\text { This study discusses analysis of United States quantitative easing } \\
\text { policy on real output in Indonesia. QE policy not only affects US } \\
\text { economy but also influences the economic indicators of other } \\
\text { countries, especially Indonesia countries with increasingly } \\
\text { integrated market conditions. At present the Indonesia economy } \\
\text { has been very open, so that policies originating from abroad can } \\
\text { affect the country's economic conditions. The possibility of global } \\
\text { spillover against non-conventional monetary policies such as QE. } \\
\text { It is using the Vector Autoreggresion (VAR) methods to see the } \\
\text { effect of QE policy. The data is time series for the 1999Q1- } \\
2016 Q 4 \text {. This study will analyze the impact of macroeconomic } \\
\text { variables such as interest rates, money supply and inflation on } \\
\text { GDP. The results of this study indicate that the implementation of } \\
\text { the QE policy has an impact on the rate of GDP growth in each } \\
\text { country of Indonesia }\end{array}$} \\
\hline $\begin{array}{l}\text { Keywords } \\
\text { Quantitative Easing, GDP, Vector } \\
\text { Autoreggresion (VAR) }\end{array}$ & \\
\hline Corresponding Author & \\
\hline Email:sebastiana@unej.ac.id & \\
\hline
\end{tabular}

\section{Introduction}

The global financial crisis that occurred in September 2008 caused the government and central banks around the world to take various actions in stabilizing financial conditions. The instability of the financial conditions caused uncertainty that was responded to by many countries with quite intensive policies, both conventional monetary policy and unconventional monetary policy.

Before Lehman Brothers suffered bankruptcy in September 2008, policy measures taken by central banks in many countries focused more on efforts to ease liquidity tensions by injecting large amounts of funds into the financial system. At the same time, central banks in developed and developing countries also continued to maintain macroeconomic stability through adjustments to interest rates to almost zero percent in several developed countries such as the United States and Britain after the 2008 economic crisis shown by Figure 1 . However, since the bankruptcy of Lehman Faculty of Economics and Business, Brawijaya University
Brothers, policy holders in various countries assessed the existence of a series of conventional policies that have been taken, but not enough to overcome the problems with aggregate demand and credit crunch (Dornbusch et al, 2008: 250 )

The bankruptcy of Lehman Brothers in September 2008 caused direct shocks to developing countries (Dooley \& Hutchison, 2009). The beginning of the global economic financial crisis emerged since August 2007. Where one of the largest banks in France, BNP Paribas, announced a freeze on several securities related to subprime mortgages.

Figure 1. Interest rate in USA and UK 


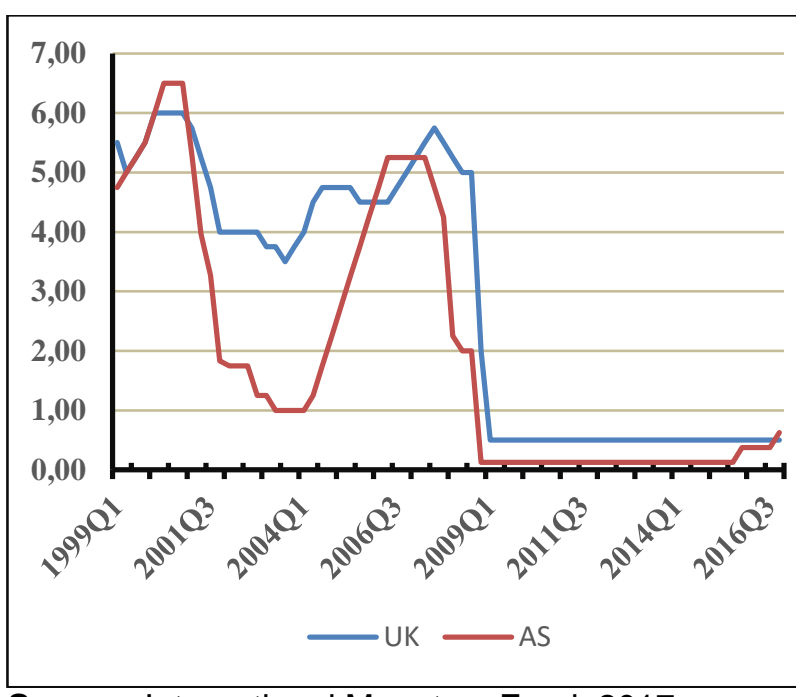

Source: International Monetary Fund, 2017

The Federal Reserve (The Fed) takes an action in taking one of the unconventional policies, namely Quantitative Easing (QE). In 2007, the Fed carried out expansive monetary policy in an effort to stimulate economic growth. One of the important things in this effort is to buy short-term government bonds through open market operations. By purchasing these assets, the Fed adds liquidity to the economy. The purchase is expected to increase economic activity because there is an addition to reserves or liquidity to the conventional banking system. So that, banks can increase lending more money and increase profits. However, because of the ineffectiveness of this open market operation, the Fed carried out an action to stimulate Wright's economic growth (2012).

Quantitative easing (QE) leads to changes in the composition or size of a central bank's balance sheet designed to increase liquidity and credit. Where this is done by purchasing large amounts of long-term securities, including government bonds (treasuries), bond agencies, and agency mortgage backed securities. In Indonesia, most people assume that non-conventional monetary policy instruments such as overnight interest rates will be better than $\mathrm{QE}$. Although the central bank can cut nominal interest rates to touch zero percent, it still cannot stimulate economic conditions at that time. Where at that time the nominal interest rate has touched zero percent which is called the liquidity trap (Krugman, 1998).

At the time of the 2008 global crisis, ASEAN economic fundamentals were far better than during the 1998 Asian crisis. This can be seen from economic growth, debt burden, balance of foreign balance sheets, and conditions of bank credit. Although the conditions of macroeconomic fundamentals were very good in 2008, ASEAN countries remained affected by the crisis in the form of exchange rate speculation attacks, capital outflows which resulted in reduced foreign exchange reserves, and falling stock and bond prices. From the experience of the 1998 Asian crisis, ASEAN countries were more careful in managing foreign debt, especially short-term debt.

\section{Literature Review}

\section{The Understanding of Quantitative of Easing} Policy

Quantitative easing is a monetary policy implemented by the central Bank to increase amount of money in circulation in order to increase the level of the economy by buying various long-term assets in the form of government securities or commercial banks. This kind of monetary policy is pursued with the excuse of creating inflation to prevent the risk of deflation.In the quantitative easing policy, the central bank will increase the money supply in the market and encourage every commercial bank to be willing to provide loans or credit, be it for business or for consumptive purposes to companies and the public. For this reason, in the implementation of this monetary policy, there will be a decrease in short-term interest rates, even reaching $0 \%$. The hope is that low interest rates can encourage companies and the public to want to borrow or credit. Increasing the level of credit is expected to increase the level of the community's economy on a micro or macro basis. Furthermore, the consumption level of each community and company is also expected to increase. In this way, the business activities of the community and companies will be able to improve and even enhance the economic development of the country at large (Ugai,2007)

The Importance of Quantitative Easing Policy Implication

The sluggishness and economic crisis are the main reasons for the need for quantitative easing policies. When the country's economy is in crisis, some business sectors are sluggish, the unemployment rate is rising, demand is low, it is certain that people's income levels will be low. By implementing a quantitative easing policy, the amount of money circulating in the community will increase and be accompanied by a decrease in short-term interest rates to a level that can reach $0 \%$. The goal is that people and companies can apply for short-term loans with low interest rates. The provision of loans to companies and the 
community is expected to be able to encourage expenditure levels or increase public consumption. When this condition occurs, the level of demand or public spending on various goods will also increase. This condition will also increase production activities in order to be able to meet the demands of the community. Thus, the economy will slowly stabilize as expected (Krishnamurthy,2011). The quantitative easing monetary policy imposed by a certain country will have an impact on the global economy.

The increase in the amount of money circulating in the market will be allocated to purchase securities and distribute loans that are not only able to reach the national market, but are also able to penetrate the international market, even bilateral relations in each country in its economic sector. So in principle, quantitative easing will have a positive effect on the stock price index. The large amount of money in circulation also has the potential to increase investment, so that it will be able to cause capital inflows, namely capital inflows related to the purchase of various securities. If the rate of return offered is quite high, then the value of this capital inflow will trigger inflation. In addition, the rapid flow of investment that cannot be matched by an increase in the real sector will risk causing new problems, namely capital flight, especially in developing countries (Girardin,2011)

\section{Research Method}

Data samples used from the period $2000 q 1$ to $2016 q 4$ include real output data in each of Indonesia. As the dependent variable is the level of GDP in Indonesia and the independent variables namely interest rates, inflation, the money supply (M2) of the United States.

Data is taken from various sources including the International Monetary Fund (IMF), World Bank, International Financial Statistics, Bank Indonesia and Bloomberg.

This study uses the Vector Auto Regressive (VAR) analysis method to see the behavior of individuals from each country studied and to use time series data from 2000 to 2016 . The VAR method is to see the overall (aggregate) or cross-sectional dimension in Indonesia as in the study empirical by Halova (2015).

The Vector Auto Regressive (VAR) method was developed by an Econometrics expert, Chistopher A. Sims, as an alternative estimator of the multiple equation model with the consideration of minimizing the development of theory that aims to capture economic phenomena well (Widarjono, 2007). Sims suggests that if there is a simultaneous

Faculty of Economics and Business,

Brawijaya University relationship between the variables studied, then the variable must be treated equally so that there are no endogenous variables and exogenous variables. (Nachrowi, 2006).

\section{Equations}

The VAR model does not depend much on theory but only needs to determine the variables that interact with each other and determine the number of pauses and include them in the model which are expected to capture the relationship between the variables observed in the model. Following are the VAR time series models:

\section{$\mathrm{GDP}_{\text {IND }}=\mathrm{f}\left(\right.$ Interest rate, $\mathrm{M} 2_{\mathrm{AS}}$, Inflation $\left.\mathrm{AS}\right)$}

The VAR model equation with a lag length in this study can be written into the form:

$A y_{t}=\beta_{0} \sum_{i=1}^{p} \Phi_{i} y_{t-i}+\epsilon_{t}$

Where, is a vector of endogan variables that contain variables in this study, whereas it is a vector of structural disturbances (structural random error term). For example, if it is assumed that a vector contains two endogenous variables, if it is described, the model becomes:

$$
\begin{aligned}
& A=\left(\begin{array}{lr}
1 & -\alpha_{12} \\
-\alpha_{21} & 1
\end{array}\right), y_{t}=\left(\begin{array}{l}
y_{1 t} \\
y_{2 t}
\end{array}\right), \beta=\left(\begin{array}{l}
\beta_{10} \\
\beta_{20}
\end{array}\right) \\
& \Phi=\left(\begin{array}{ll}
\gamma_{11}^{i} & \gamma_{12}^{i} \\
\gamma_{21}^{i} & \gamma_{22}^{i}
\end{array}\right), \epsilon_{t}=\left(\begin{array}{l}
\epsilon_{1 t} \\
\epsilon_{2 t}
\end{array}\right)
\end{aligned}
$$

The above model is named as a structural form of the VAR model. The model cannot be estimated using OLS because the variable correlates with the error term so that and because there is an assumption that endogenicity causes the Gauss-Markov theorem to be rejected. The above shrinkage model of VAR (reduced form of VAR) can be obtained by reversing it with a matrix so that it is obtained:

$y_{t}=\mu \sum_{i=1}^{p} \Pi_{i} y_{t-i}+e_{t}$

where:, and. The above model is called the VAR shrinkage model because each equation only contains the lag value of all endogenous variables in the system. While the VAR panel model in this study can be represented in the equation model:

$y_{i, t}=\mu_{i} \sum_{j=1}^{p} \Pi_{i, j} y_{i, t-j}+e_{i, t}$

\section{Results and Discussion}

Based on the VAR estimation results shown in Table 1, it can be seen that the interest rate variable and the money supply have a positive influence on real GDP in Indonesia, but the effect is not significant in the first period. 
While the inflation variable in the US has a negative and significant effect on real GDP in Indonesia with a probability value of 0.04253 where the value is smaller than the value of $\alpha=$ $5 \%$. This indicates that when in the United States there is an increase in inflation, then Indonesia's real GDP will decline.

Tabel 1. Results of Estimating the VAR Model

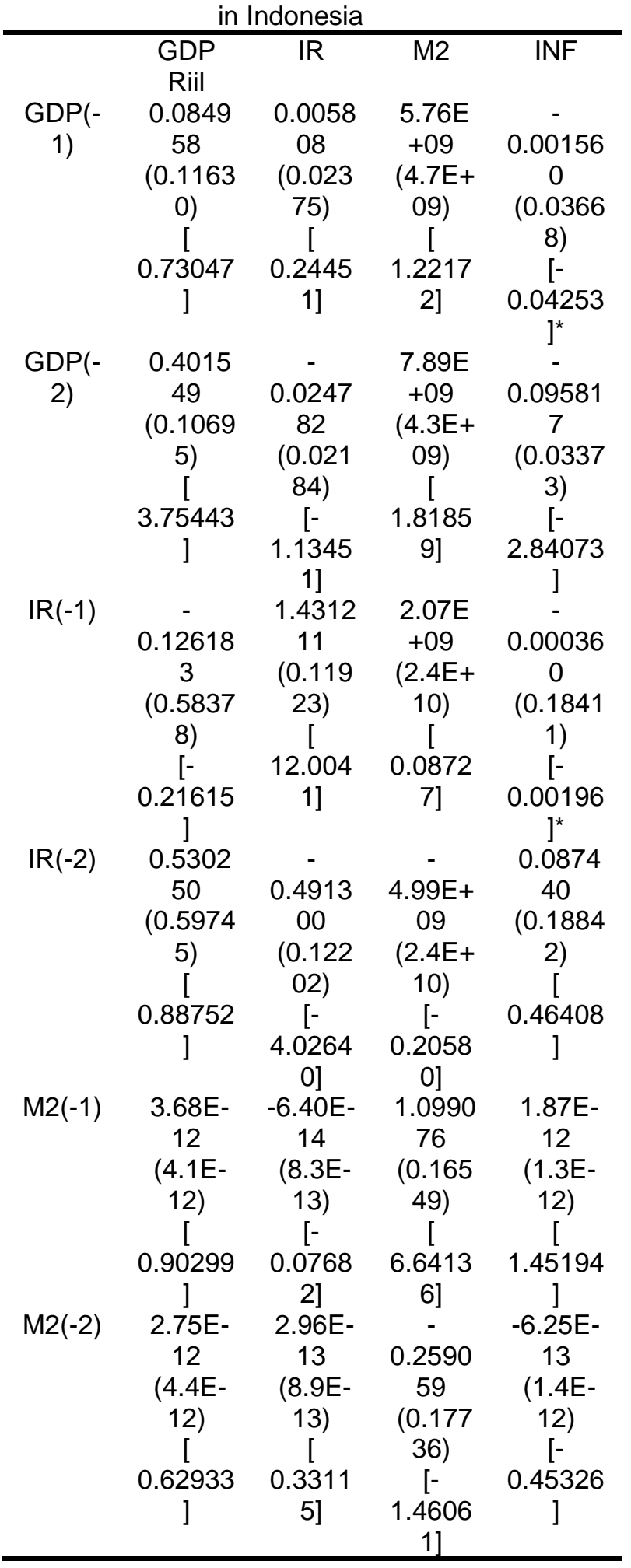

\begin{tabular}{|c|c|c|c|c|}
\hline $\operatorname{INF}(-1)$ & $\begin{array}{c}0.11242 \\
1 \\
(0.4944 \\
7) \\
{[-} \\
0.22736 \\
]\end{array}$ & $\begin{array}{c}0.1082 \\
48 \\
(0.100 \\
99) \\
{[-} \\
1.0719 \\
0]\end{array}$ & $\begin{array}{c}1.57 \mathrm{E} \\
+10 \\
(2.0 \mathrm{E}+ \\
10) \\
{[} \\
0.7814 \\
9]\end{array}$ & $\begin{array}{c}1.2108 \\
64 \\
(0.1559 \\
4) \\
{[} \\
7.76494 \\
]\end{array}$ \\
\hline $\operatorname{INF}(-2)$ & $\begin{array}{c}- \\
0.23220 \\
0 \\
0.5049 \\
7) \\
{[-} \\
0.45983 \\
]\end{array}$ & $\begin{array}{c}0.0813 \\
68 \\
(0.103 \\
13) \\
{[} \\
0.7889 \\
7]\end{array}$ & $\begin{array}{c}- \\
2.61 \mathrm{E}+ \\
09 \\
(2.0 \mathrm{E}+ \\
10) \\
{[-} \\
0.1273 \\
9]\end{array}$ & $\begin{array}{c}- \\
0.30634 \\
4 \\
(0.1592 \\
5) \\
{[-} \\
1.92364 \\
]\end{array}$ \\
\hline C & $\begin{array}{c}24.641 \\
42 \\
(8.6159 \\
5) \\
{[} \\
2.85998 \\
]\end{array}$ & $\begin{array}{c}2.3815 \\
39 \\
(1.759 \\
66) \\
{[} \\
1.3534 \\
1]\end{array}$ & $\begin{array}{c}- \\
9.85 \mathrm{E}+ \\
11 \\
(3.5 \mathrm{E}+ \\
11) \\
{[-} \\
2.8167 \\
8]\end{array}$ & $\begin{array}{c}7.1790 \\
80 \\
(2.7172 \\
0) \\
{[} \\
2.64209 \\
]\end{array}$ \\
\hline $\begin{array}{l}\text { R- } \\
\text { square } \\
\text { d } \\
\text { Adj. } \\
\text { R- } \\
\text { square } \\
\text { d }\end{array}$ & $\begin{array}{c}0.9911 \\
43 \\
0.9899 \\
81\end{array}$ & $\begin{array}{c}0.9681 \\
61 \\
0.9639 \\
85\end{array}$ & $\begin{array}{c}0.9989 \\
17 \\
0.9987 \\
75\end{array}$ & $\begin{array}{c}0.9964 \\
29 \\
0.9959 \\
61\end{array}$ \\
\hline
\end{tabular}

Based on the VAR estimation results shown in Table 1, it can be seen that the interest rate variable and the money supply have a positive influence on real GDP in Indonesia, but the effect is not significant in the first period. While the inflation variable in the US has a negative and significant effect on real GDP in Indonesia with a probability value of 0.04253 where the value is smaller than the value of $\alpha=$ $5 \%$. This indicates that when in the United States there an increase in inflation is, then Indonesia's real GDP will decline.

The next step after estimating the VAR model is the Impulse Response Function (IRF) analysis. The purpose of the IRF is to describe the effect of shock or shock from endogenous variables on other endogenous variables contained in the model. This study describes the effect of the interrelationship between real GDP variables in each ASEAN country 4 and the Quantitavie Easing (QE) policy indicators conducted by the United States (US). The following are the results of the Impulse Response Function (IRF) for Indonesia.

Figure 1. Impulse Response Function 

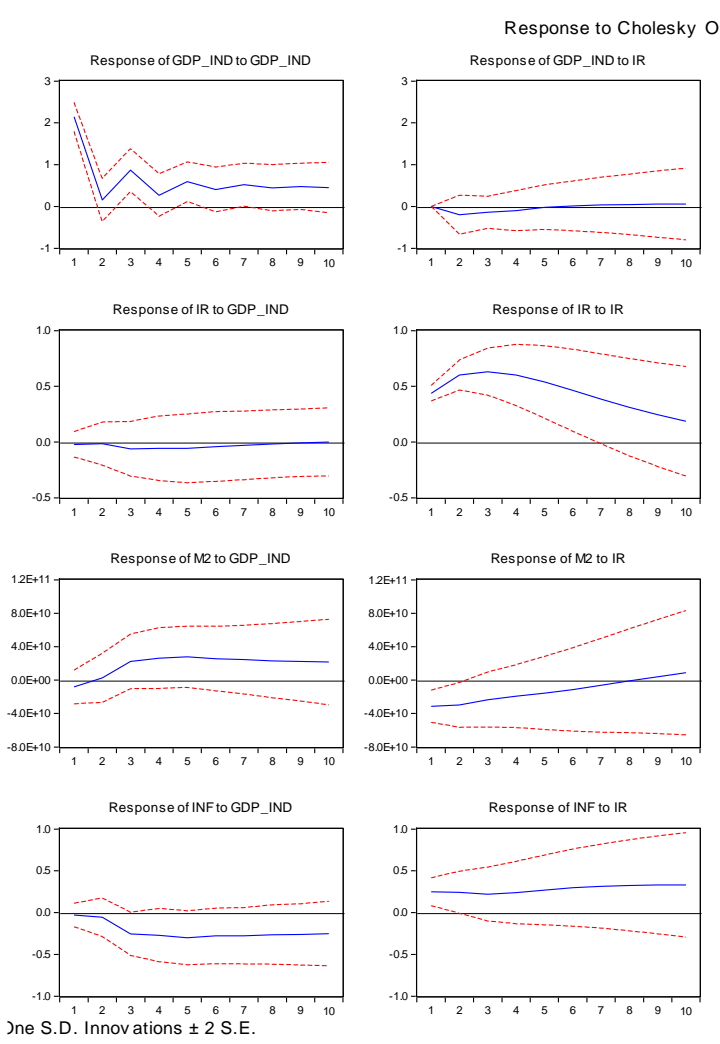

Response of GDP_IND to NR
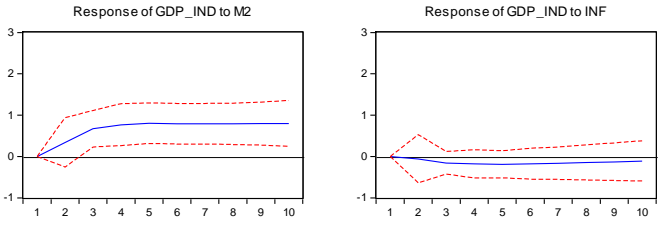

Response of IR to M2
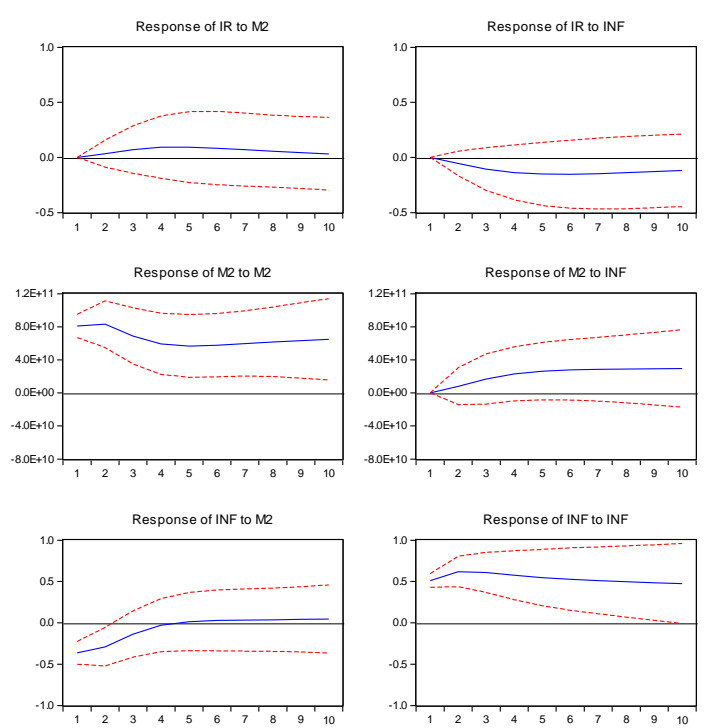

Source: Author's Analysis

In Figure 1 it can be seen that US interest rates are responded to by real GDP in Indonesia since the first period. This is shown by the red line on the graph that illustrates the relationship between US interest rates and Indonesian real GDP. Until the 10th period of shocks to US interest rates tended to be responded to stably by real GDP in Indonesia. While the shock of the US money supply (M2) tends to be responded to stably by Indonesia. The IRF chart does not show a drastic movement so that despite changes in the amount of US money supply, the Indonesian economy will tend to be stable. Shocks to US inflation were responded to since the first period by Indonesia's real GDP and subsequently showed a stable movement.

The estimation of the VAR model to explain the proportion or contribution of endogenous variables in the model can also be seen in the form of Variance Decomposition (VD). The difference between Impulse Response Function (IRF) and Variance Decomposition (VD) is that it is present only in appearance. If the IRF variable movement is depicted in graphical form, then in VD the movement of variables can be described in the table (percentage contribution). The following will be explained about the results of Variance Decomposition (VD) in Indonesia.

Tabel 2. Variance Decomposition

\begin{tabular}{|c|c|c|c|c|c|}
\hline rio & S.E. & $\begin{array}{c}\text { GDP_IN } \\
\text { D }\end{array}$ & IR & M2 & INF \\
\hline & 2.14528 & 100.000 & 0.00000 & 0.0000 & 0.0000 \\
\hline 1 & 5 & 0 & 0 & 00 & 00 \\
\hline & 2.18735 & 96.7110 & 0.82572 & 2.3939 & 0.0692 \\
\hline 2 & 7 & 9 & 9 & 78 & 03 \\
\hline 3 & $\begin{array}{c}2.45513 \\
5\end{array}$ & 89.2067 & 0.98730 & $\begin{array}{c}9.3428 \\
08\end{array}$ & 0.4631 \\
\hline 4 & $\begin{array}{c}2.59429 \\
3\end{array}$ & $\begin{array}{c}80.9637 \\
2\end{array}$ & $\begin{array}{c}1.03758 \\
2\end{array}$ & $\begin{array}{c}17.096 \\
86\end{array}$ & $\begin{array}{c}0.9018 \\
39\end{array}$ \\
\hline 5 & $\begin{array}{c}2.78615 \\
2\end{array}$ & $\begin{array}{c}74.7176 \\
4\end{array}$ & $\begin{array}{c}0.90478 \\
1\end{array}$ & $\begin{array}{c}23.119 \\
42\end{array}$ & $\begin{array}{c}1.2581 \\
55\end{array}$ \\
\hline 6 & $\begin{array}{c}2.92981 \\
0\end{array}$ & $\begin{array}{c}69.4956 \\
8\end{array}$ & $\begin{array}{c}0.81983 \\
9\end{array}$ & $\begin{array}{c}28.178 \\
00\end{array}$ & $\begin{array}{c}1.5064 \\
81\end{array}$ \\
\hline 7 & $\begin{array}{c}3.08330 \\
0\end{array}$ & $\begin{array}{c}65.5885 \\
8\end{array}$ & $\begin{array}{c}0.75667 \\
6\end{array}$ & $\begin{array}{c}32.008 \\
65\end{array}$ & $\begin{array}{c}1.6460 \\
89\end{array}$ \\
\hline 8 & $\begin{array}{c}3.21724 \\
2\end{array}$ & $\begin{array}{c}62.1633 \\
4\end{array}$ & $\begin{array}{c}0.71595 \\
6\end{array}$ & $\begin{array}{c}35.402 \\
03\end{array}$ & $\begin{array}{c}1.7186 \\
76\end{array}$ \\
\hline 9 & $\begin{array}{c}3.35110 \\
2\end{array}$ & $\begin{array}{c}59.3379 \\
2\end{array}$ & $\begin{array}{c}0.68625 \\
8\end{array}$ & $\begin{array}{c}38.242 \\
82\end{array}$ & $\begin{array}{l}1.7330 \\
05\end{array}$ \\
\hline 10 & $\begin{array}{c}3.47599 \\
0\end{array}$ & $\begin{array}{c}56.8102 \\
3\end{array}$ & $\begin{array}{c}0.66517 \\
3\end{array}$ & $\begin{array}{c}40.812 \\
94\end{array}$ & $\begin{array}{c}1.7116 \\
57\end{array}$ \\
\hline
\end{tabular}

Source: Author's Analysis

In Table 2 shows the results of Variance Decomposition (VD) in Indonesia in that it can be seen the movement of QE policy indicator variables on real GDP in Indonesia. In the first period, there has not been a shock response to the variable interest rates, the money supply and inflation in the US. The response has occurred 
since the second period. The interest rate of the member contributes around $82 \%$, the money supply is around $239 \%$ and inflation is $6.9 \%$.

\section{Conclusion}

Based on the results obtained from all stages of the VAR analysis that the relationship that occurs in variable interest rates, inflation and the United States money supply to the GDP variable in Indonesia is significant in the long run, the results obtained from the error correction coefficient (error correction), even though adjustments occur in the long-term balance, but adjustments tend to be slow, and these variables do not have a short-term relationship. Only longterm balance adjustments are needed.

\section{References}

Andrew, T. Foerster, Financial Crises. 2016. Unconventional Monetary Policy Exit Strategies, and Agents' Expectations, Journal of Monetary Economics, http://dx.doi.org/10.1016/i.jmoneco.201 5.10 .001

Bowman, David, et al. 2013. U.S. Unconventional Monetary Policy and Transmission to Emerging Market Economies. Journal of International Money and Finance. 10.1016/j.jimonfin.2015.02.016

Chen, Qianying, et,al. 2015. US unconventional monetary policy and international spillovers, Journal of International Money and

Finance, http://dx.doi.org/doi:10.1016/i.jimonfin.2 015.06 .011$.

Dreger, Christian dan JürgenWolters. 2015. Unconventional monetary policy and money demand. Journal of Macroeconomics. page 40-54

Fisher, Nathan Foley. 2016. The impact of unconventional monetary policy on firm financing constraints: Evidence from the maturity extension program. Journal of Financial Economics

Girardin, E., \& Moussa, Z. (2011). Quantitative easing works: Lessons from the unique experience in Japan 2001-2006. Journal of International Financial Markets, Institutions and Money, 21(4), 461-495.

Guidolin, Massimo. 2014. Unconventional monetary policies and the corporate bond market. Finance Research Letters

Hännikäinen, Jari. 2015 Zero lower bound, unconventional monetary policy and indicator properties of interest rate spreads. Review of Financial Economics Kiendrebeogo, Youssouf. 2016. Unconventional monetary policy and capital flows. Economic Modelling. Page 412-424

Krishnamurthy, A., \& Vissing-Jorgensen, A. (2011). The effects of quantitative easing on interest rates: channels and implications for policy (No. w17555). National Bureau of Economic Research.

Kucharcuková, Oxana Babecká. 2016. Spillover of the ECB's monetary policy outsidethe euro area: How different is conventionalfrom unconventional policy? Journal of Policy Modeling. page 199-225

Kuncoro, Mudrajad. 2003. Metode Riset untuk Bisnis dan Ekonomi. Jakarta : Erlangga Liang, Fang and Weiya Huang, 2011. "The Relationship Between Money Supply and the GDP of United States". Hong Kong Baptist University : Hong Kong

Lutz, C. 2015. The Impact of Conventional and Unconventional Monetary Policy on Investor Sentiment, Journal of Banking \& Finance, $\quad$ doi: http://dx.doi.org/10.1016/j.jbankfin.2015. 08.019

Neely, Christopher J. 2015. Unconventional monetary policy had large international effects. Journal of Banking \& Finance. page 101-111

Rahal, Charles. 2016. Housing markets and unconventional monetary policy. Journal of Housing Economics. page 67-80

Tillmann, Peter. 2016. Unconventional monetary policy and the spillovers to emerging markets. Journal of International Money and Finance. http://dx.doi.org/doi: 10.1016/j.jimonfin.2015.12.010

Ugai, H. (2007). Effects of the quantitative easing policy: A survey of empirical analyses. Monetary and economic studies-Bank of Japan, 25(1), 1.

Wang, Ling. 2016. Unconventional monetary policy and aggregate banklending: Does financial structure matter? Journal of Policy Modeling 